\title{
Development and application of an automated, multiwell plate based screening system for suspension cell culture
}

\author{
Sven Markert", Carsten Musmann, Klaus Joeris \\ From 23rd European Society for Animal Cell Technology (ESACT) Meeting: Better Cells for Better Health \\ Lille, France. 23-26 June 2013
}

\begin{abstract}
Introduction
The already presented automated, multiwell plate (MWP) based screening system for suspension cell culture is now routinely used in process development. It is characterized by a fully automated workflow with integrated analytical instrumentation and uses shaken 6-24 well plates as bioreactors which can be run in batch and fed-batch mode with a capacity of up to 384 reactors in parallel [1].

A wide ranging analytical portfolio is available to monitor cell culture processes and to characterize product quality. Assays running on the screening system comprise the determination of cell concentration and viability, quantification of nutrients and metabolites as well as detection of apoptosis level and staining of organelles. Additionally a RT-qPCR method has been setup to measure gene expression level in a high throughput manner. Having a large network in-house to high throughput groups of the analytical department a lot of advanced methods can easily be performed like chromatographic and mass spectrometry to characterize product quality.

Current work focuses on expanding the analytical portfolio to develop control strategies for automated cell culture processes. Besides setting up a robust method for $\mathrm{pH}$ measurement we evaluate different spectroscopic techniques like Raman, infrared or 2D fluorescence as fast and powerful analytical tools.
\end{abstract}

\section{Results}

Scale-up prediction

The comparability of results obtained with multiwell plates and bioreactors had to be verified to develop a screening system for the predictive scale-up.

\footnotetext{
* Correspondence: Sven.Markert@roche.com

Roche Diagnostics GmbH, Pharma Biotech Production and Development, Penzberg, Germany
}

\section{Application of $\mathrm{pH}$ measurement and $\mathrm{pH}$ control}

A fully automated, multiwell plate based $\mathrm{pH}$ measurement assay and a $\mathrm{pH}$ control strategy was developed for the screening system. The established assay is based on the use of $\mathrm{pH}$ sensitive absorption and fluorescent dyes which are added to a cell culture sample. The advantages of this method comprise a short analytical time and the low sample volume per sample. The assay is characterized by a high precision and robustness without any probe drift during a cultivation time of up to two weeks.

The successful application of the developed $\mathrm{pH}$ measurement and $\mathrm{pH}$ control could be confirmed by getting comparable $\mathrm{pH}$ profiles from MWP and bioreactor under the same conditions and can be kept equal by controlling the $\mathrm{pH}$ (Figure 1A).

In a second experiment a $\mathrm{pH}$ shift of $0.4 \mathrm{pH}$ values after 72 hours was performed (Figure 1B). The target $\mathrm{pH}$ was reached exactly and it could be controlled at a stable level using the developed $\mathrm{pH}$ measurement assay.

\section{Feasibility of Raman spectroscopy as high throughput analytical tool}

Raman spectroscopy is a powerful tool for the detection and quantification of several components in cell culture processes at once. Using this fast and non-invasive
Using several late stage project cell lines growing in suspension the comparability of results obtained with automated, shaken multiwell plates and bioreactors with
a volume of up to $1.000 \mathrm{~L}$ could be verified. The effects of process optimization steps on cell culture performance and product quality were shown in multiwell screening system can be used for scale up prediction. 

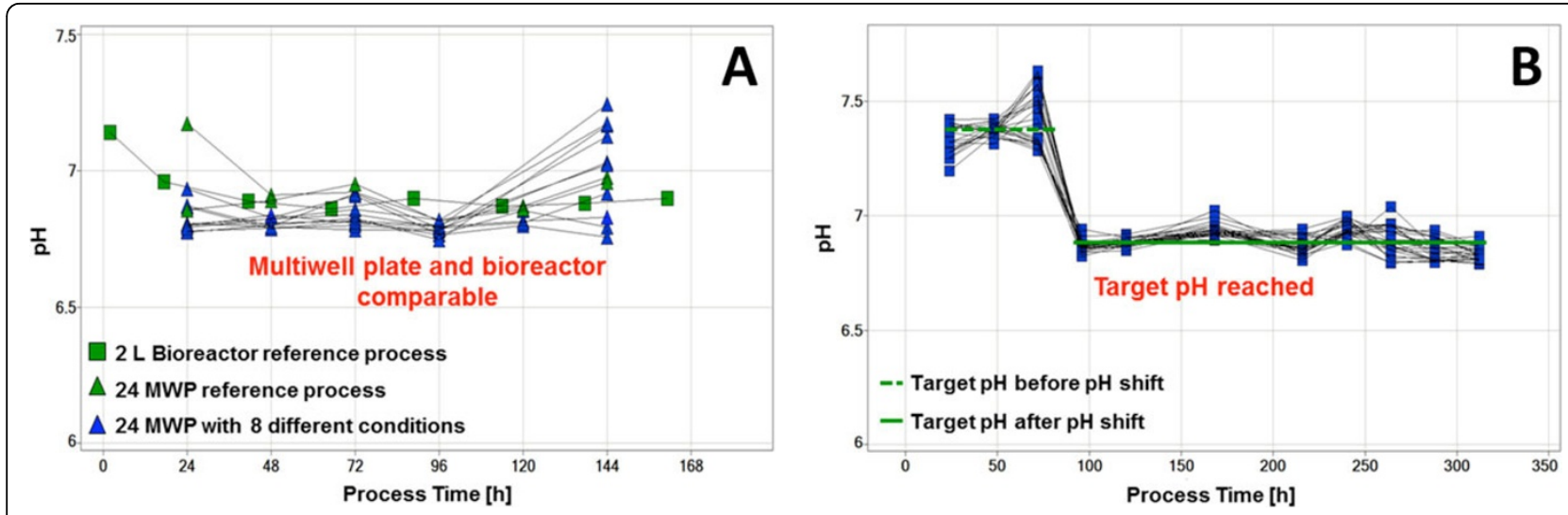

Figure 1 (A) Comparability of the $\mathrm{pH}$ profile between the MWP reference process and the $\mathbf{2 L}$ bioreactor reference process. Additionally further $\mathrm{pH}$ profile and product concentration under different media compositions. (B) $\mathrm{pH}$ sensitive process with $\mathrm{pH}$ shift. The target $\mathrm{pH}$, before and after the shift, was achieved by $\mathrm{pH}$ control.

analytical technique there will be no reagent costs and no sample consumption what this technique makes ideal for small scale high throughput systems.

The feasibility of Raman spectroscopy was shown for the quantification of different metabolites and nutrients, i.e. glucose, lactate and glutamine. For the quantification of glucose $(0 \mathrm{~g} / \mathrm{L}$ to $20 \mathrm{~g} / \mathrm{L})$, lactate $(0 \mathrm{~g} / \mathrm{L}$ to $10 \mathrm{~g} / \mathrm{L})$ and glutamine $(0 \mathrm{~g} / \mathrm{L}$ to $20 \mathrm{~g} / \mathrm{L})$ a good correlation with a high prediction accuracy could be shown.

\section{Conclusions and outlook}

The developed robotic screening system is capable of performing a fully automated workflow consisting of incubation, sampling, feeding and near real-time analytics. In the performed experiments the scalability from $\mathrm{mL}$ scale up to $1000 \mathrm{~L}$ scale could be shown.

Expanding the analytical portfolio a robust and fast $\mathrm{pH}$ measurement assay was developed to enable $\mathrm{pH}$ control in multiwell plates. This assay as well as $\mathrm{pH}$ control was tested during the cultivation of two late stage project cell lines resulting in comparable $\mathrm{pH}$ profiles and cell culture performance. These results enable the routinely use of the developed $\mathrm{pH}$ measurement and control strategy. Additionally the proof of concept for Raman spectroscopy as a powerful tool for the quantification of metabolites and nutrients for the automated screening system could be shown. Further spectroscopic techniques using infrared or fluorescence will be evaluated.

\section{Acknowledgements}

The authors would like to thank all internship and diploma students (R. Wetzel, K. Moeser, P. Linke, S. Spielmann, K. Müller, B. Frommeyer, J. Wisbauer), the Roche Penzberg pilot plant and GMP facility team, all Roche Penzberg portfolio project teams and the University of Hannover (Prof. Dr. Thomas Scheper, Dr. D. Solle).

\section{Published: 4 December 2013}

\section{Reference}

1. Markert $\mathrm{S}$, Joeris $\mathrm{K}$ : Development of an automated, multiwell plate based screening system for suspension cell culture. BMC Proc 2011, 5(Suppl 8): O9, Nov 22.

doi:10.1186/1753-6561-7-S6-P113

Cite this article as: Markert et al:: Development and application of an automated, multiwell plate based screening system for suspension cell culture. BMC Proceedings 2013 7(Suppl 6):P113.
Submit your next manuscript to BioMed Central and take full advantage of:

- Convenient online submission

- Thorough peer review

- No space constraints or color figure charges

- Immediate publication on acceptance

- Inclusion in PubMed, CAS, Scopus and Google Scholar

- Research which is freely available for redistribution 